\title{
PRELIMINARY DATA ON THE BEETLE (COLEOPTERA) FAUNA OF TUROPOLJSKI LUG FOREST
}

\section{PRELIMINARNI PODACI O FAUNI KORNJAŠA (Coleoptera) TUROPOLJSKOG LUGA}

\author{
Mladen ZADRAVEC* ${ }^{*}$, Toni KOREN¹, Boris LAUŠ ${ }^{1}$, Ivona BURIĆ ${ }^{1}$, Barbara HORVATIĆ ${ }^{1}$
}

\begin{abstract}
SUMMARY
Wetlands provide many important ecosystem services, e.g. serving as natural retention areas to prevent flooding and they can be recreational areas for the general public. They also represent vital habitats for many animal species and many are protected nature areas. In spite of this, the fauna of many wetlands in Croatia is still mostly unknown, especially when it comes to beetles. Not knowing the fauna of a particular habitat hinders management efforts. One such location is Turopoljski Lug forest, south-east from the capital Zagreb. The fieldwork was done from March till September 2017, utilising four methods: sweep netting, baited traps on tree trunks, light trapping with UV light traps at night, and collecting by hand. Additionally, several records from earlier visits are included. The total number of currently known species for the forest is raised from 51 to 133. A total of nine species are near threatened (NT), seven of which are saproxylic. Three species listed in Annexes II and IV of the Habitats Directive occur in the area, of which only Cerambyx cerdo had been recorded. Additionally, a neglected literature record of a fourth, Phryganophilus ruficollis, has been discovered. Current management practices for the forest should be re-evaluated and modified if necessary. Future research targeting specific beetle groups should yield further increases in the number of species known for the area, while a targeted mapping of the distribution of species listed on the Annexes should yield much-needed conservation information.
\end{abstract}

KEY WORDS: flooded forest, Natura 2000 Ecological Network, Cerambyx cerdo, Phryganophilus ruficollis, Trox perrisii, nature protection areas

\section{INTRODUCTION UVOD}

Wetlands represent important habitats for many animal species, as a suitable home for them and as a source of food and water (Junk et al., 2013). Many are globally protected through the Ramsar Convention (Anonymous, 2008) and through local/national legislation, e.g. as national and nature parks and through ecological networks such as Natura 2000 (Anonymous, 1979, 1992). Examples of such wetlands in Croatia are the Kopački Rit and Lonjsko Polje Nature Parks and Natura 2000 sites, and Turopoljski Lug in Turopolje.

Turopolje is a region located between the right bank of the Sava River to the north-east and the Vukomeričke Gorice to the south-west, south-east of Zagreb and Velika Gorica, north-west of Sisak (Lazowski, 1910). One of its defining features is the Turopoljski Lug forest, covering an area of $33.44 \mathrm{~km}^{2}$. The area changed a lot in the last 200 -odd years,

* Mladen Zadravec mag. biol. exp., Dr. sc. Toni Koren, Boris Lauš, Ivona Burić mag. oecol. et prot. nat., Barbara Horvatić mag. biol. exp., Association Hyla, Lipovac I no. 7, 10000 Zagreb, Croatia, E-mail: mladen.zadravec@hhdhyla.hr, toni.koren@hhdhyla.hr, boris.laus@hhdhyla.hr, ivona.buric@hhdhyla.hr, barbara.horvatic@hhdhyla.hr 
mainly due to the shift from an acorn-harvesting to a lumber-harvesting attitude by the people from the area and the expansion of the villages (Tvrtković, 1997a). This is evident in the reduction of the Turopoljski Lug forest's surface area, as is evident comparing the First Military Survey maps created during the Habsburg Monarchy (Biszak et al., 2014) with modern sources (e.g. Google Earth). While the reduction in the number of bogs and other wetlands was evident by the beginning of the $20^{\text {th }}$ century (Lazowski, 1910), one of the major changes when it comes to the water regime and wetland habitats was when the Sava-Odra canal was dug in 1965 , to divert excess water from the Sava River away from Zagreb, as a flood prevention measure (Tvrtković, 1997a). This, and other flood prevention measures implemented throughout the years, caused a shift in the groundwater levels (Tvrtković, 1997a). Additionally, the wet grassland habitats are either drying out, or disappearing due to overgrowing. Despite this, Turopoljski Lug is still considered to be one of the most important wetland habitats in Croatia, and as such is covered by the Natura 2000 site Odransko Polje (HR2000415) (Anonymous, 2015), and the Significant Landscapes Turopoljski Lug and Odransko Polje (Anonymous, 2003).

There are only four literature sources covering the beetle fauna of Turopoljski Lug, listing a total of 51 species (Anonymous, 2015; Mikšić, 1963; Schlosser, 1878; Vujčić-
Karlo and Klipa, 1998). Of those, 44 are of the Carabidae family - a result of the only as of yet systematic beetle inventory work carried out there (Vujčić-Karlo and Klipa, 1998). Based on this, it can be said that the beetle fauna of Turopolje is very poorly known. Since conservation and management should be evidence-based (Sutherland et al., 2004), and since beetles are an important component of many habitat communities as herbivores, predators and decomposers (Cálix et al., 2018; Petersen and Luxton, 1982), this lack of basic data of an important lowland forest represents a critical gap in the foundation for future actions.

To partly fill this gap and provide additional information useful for conservation and management actions in the future, we present an overview of the currently known beetle species for Turopoljski Lug, based on literature and newly collected field data.

\section{MATERIALS AND METHODS MATERIJALI I METODE}

To perform a broad screening of the beetle fauna of $\mathrm{Tu}$ ropoljski lug, 15 locations were visited from March till September 2017 (Figures 1 \& 2, Table 1). Baited traps were made from plastic 1.51 bottles by cutting off the top part of the bottles, inverting it and inserting them back into the

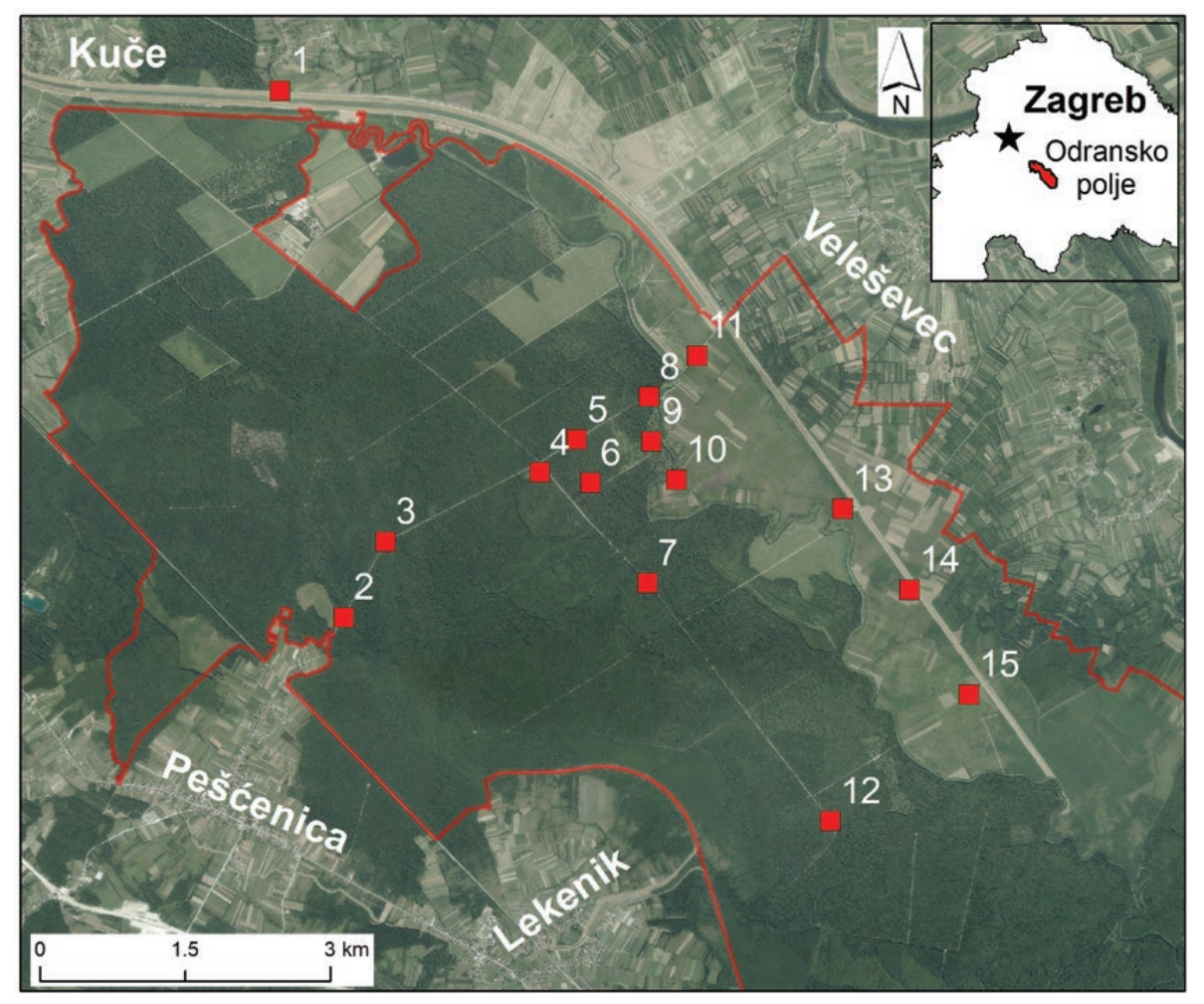

Figure 1. - Map of Turopoljski Lug showing the research locations. Location numbers correspond to those in Table 1. The border of the northwestern part of the Natura 2000 site Odransko Polje is also shown.

Slika 1. - Karta Turopoljskog luga s naznačenim istraživačkim lokacijama. Brojevi lokacija odgovaraju onima u Tablici 1. Granica sjeverozapadnog dijela Natura 2000 područja Odransko polje također je označena. 


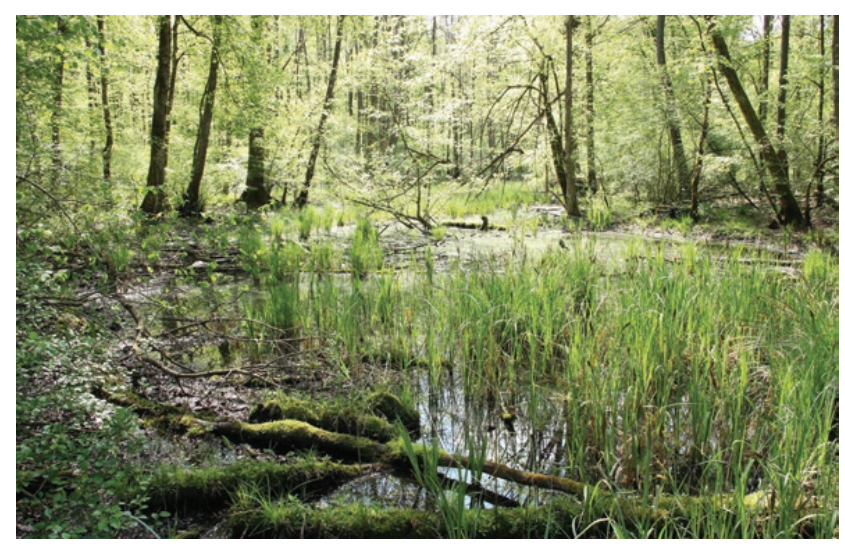

Figure 2. - A part of the Turopoljski Lug forest (photo by Vesna Zadravec). Slika 2. - Dio Turopoljskog luga (fotografija: Vesna Zadravec).

body of the bottles. This was secured using small pieces of metal wire. A mixture of white and red wine $(1: 1)$, with a few pieces of banana, was poured inside as bait. The traps were setup in three sets of five. The first two sets were set up on 13 June 2017 at locations 5 and 7, while the third set was set up on 13 July at location 4 , to provide additional screening during the peak of the activity of some saproxylic species. All three were removed on 28 September. They were emptied once a month. In order to survey nocturnal beetles, four to eight UV light traps were used three times to collect beetles at location 11, in May, July and September. Sweep netting was performed by sweeping herbaceous and low woody vegetation on all locations, on 9 April, 14 \& 29 May, 13 June, and 13 July 2017 to find beetles hiding and/or feeding within that vegetation layer, especially on flowers. Collecting by hand was carried out on all locations and represents random non-specific collecting.
Additionally, several beetle records from UV light trapping in April and September 2015 from locations 3 and 5, with some random sampling methods from March 2015 on location 4 , are also included in the results.

Specimens of species which could be reliably identified in the field were examined macroscopically and/or by using handheld magnifiers ( $10 \times$ magnification). Those that could not were collected using ethyl acetate and brought back to the lab, examined under a 1MISTBMS143T stereo microscope and their genitalia were isolated when needed for identification purposes. The usual keys were used for identification, both in the field, and in the lab (Ballerio et al., 2010; Bense, 1995; Bordy et al., 2012; Curletti et al., 2003; Freude, 1971; Laibner, 2000; Lompe, 2009; Mikšić, 1965, 1958; Nedvěd, 2015; Novák, 2014; Sama, 2002; Šustek, 1981; Trautner and Geigenmüller, 1987; Turin et al., 2003; Warchałowski, 2010, 2003). All collected specimens are deposited in the Coleoptera collection of Association Hyla. The identification of members of the Elateridae family was additionally checked by Tamás Németh from the Hungarian Natural History Museum (NHMUS). The nomenclature follows Fauna Europaea (de Jong et al., 2014).

\section{RESULTS}

\section{REZULTATI}

During the field work, and including the authors' personal records from 2015, a total of 89 beetle species were recorded, seven of which are already known from the literature. Thus, the total number of beetle species currently known for Turopoljski Lug is raised to 133 (Appendix 1). Only one of those is listed in Annexes II and IV of the Habitats Di-

Table 1. List of researched localities with their corresponding geographic coordinates (decimal degrees in the WGS84 coordinate system). Tablica 1. - Popis istraživanih lokacija s pripadajućim geografskim koordinatama (decimalni stupnjevi, WGS84 koordinatni sustav).

\begin{tabular}{|c|c|c|c|}
\hline \multirow{2}{*}{$\begin{array}{l}\text { No. } \\
\text { Br. }\end{array}$} & \multirow{2}{*}{$\begin{array}{l}\text { Location description } \\
\text { Opis lokacije }\end{array}$} & \multicolumn{2}{|c|}{ Coordinates / Koordinate } \\
\hline & & $\mathrm{N}$ & E \\
\hline & Velika Gorica, Turopoljski Lug, settlement Poljana Čička, Odra River's connection to the Sava-Odra canal & 45.669305 & 16.176613 \\
\hline 2. & Velika Gorica, Turopoljski Lug, settlement Kuče, Gornjak, canal by the macadam road from the cross towards Pešćenica & 45.620348 & 16.185326 \\
\hline 3. & Velika Gorica, Turopoljski Lug, settlement Kuče, Gornjak, canal by the macadam road from the cross towards Pešćenica & 45.627673 & 16.192087 \\
\hline & Velika Gorica, Turopoljski Lug, Vratovo Foresthouse & 45.633887 & 16.211279 \\
\hline 5. & Velika Gorica, Turopoljski Lug, settlement Kuče, Rastine, side road before the cross & 45.636975 & 16.216163 \\
\hline & $\begin{array}{l}\text { Velika Gorica, Turopoljski Lug, settlement Kuče, second macadam road to the left, south-east of the Vratovo Foresthouse, } \\
\text { towards the Odra River }\end{array}$ & 45.632954 & 16.218006 \\
\hline & Velika Gorica, Turopoljski Lug, Ostrovje & 45.623654 & 16.225611 \\
\hline & Velika Gorica, Turopoljski Lug, settlement Kuče, forest around the brige over the Odra River & 45.640965 & 16.225734 \\
\hline & Velika Gorica, Turopoljski Lug, Orle, settlement Veleševec, surroundings of the Selce Village & 45.636828 & 16.226077 \\
\hline & Velika Gorica, Turopoljski Lug, Orle, settlement Veleševec, surroundings of the Selce Village & 45.633276 & 16.229382 \\
\hline & Velika Gorica, Turopoljski Lug, Orle, settlement Veleševec, surroundings of the Selce Village, Gmajna & 45.644800 & 16.232100 \\
\hline & Velika Gorica, Turopoljski Lug, settlement Kuče, 3.5 km north-east from Lekenik & 45.601562 & 16.249953 \\
\hline & Velika Gorica, Turopoljski Lug, Pešćenka, shores of the Odra River & 45.630611 & 16.251439 \\
\hline & Velika Gorica, Turopoljski Lug, 2 km SW from the settlement Suša, Gmajne area, central meadows & 45.623111 & 16.260333 \\
\hline & Velika Gorica, Turopoljski Lug, 2 km SW from the settlement Suša, Gmajne area & 45.613375 & 16.268278 \\
\hline
\end{tabular}


Appendix 1. - List of beetle species currently known for Turopoljski Lug. Location numbers correspond to those in Table 1. IUCN statuses according to Vujčić-Karlo et al. (2007) for Carabidae, and Nieto \& Alexander (2010) for the rest. LC - Least Concern, NT - Near Threatened. ${ }^{*}$ - saproxylic species.

Dodatak 1. - Popis trenutačno poznatih vrsta kornjaša za Turopoljski lug. Brojevi lokacija odgovaraju onima u Tablici 1. IUCN statusi dani su prema Vujčić-Karlo i sur. (2007) za porodicu Carabidae te Nieto i Alexander (2010) za preostale. LC - najmanje zabrinjavajuća vrsta, NT - gotovo ugrožena vrsta. ${ }^{*}$ - saproksilna vrsta.

\begin{tabular}{|c|c|c|c|c|}
\hline $\begin{array}{l}\text { No. } \\
\text { Br. }\end{array}$ & $\begin{array}{l}\text { Species } \\
\text { Vrsta }\end{array}$ & $\begin{array}{l}\text { Literature } \\
\text { Literatura }\end{array}$ & $\begin{array}{l}\text { This research } \\
\text { Ovo istraživanje }\end{array}$ & IUCN status \\
\hline \multicolumn{5}{|c|}{ Buprestidae } \\
\hline 1. & Anthaxia fulgurans (Schrank, 1789) * & & 13 & \\
\hline 2. & Anthaxia nitidula (Linnaeus, 1758) * & & 1,13 & \\
\hline 3. & Anthaxia salicis (Fabricius, 1776) * & & 1,8 & \\
\hline \multicolumn{5}{|c|}{ Carabidae } \\
\hline 4. & Abax carinatus (Duftschmid, 1812) & Vujčić-Karlo \& Klipa (1998) & & \\
\hline 5. & Abax parallelus (Duftschmid, 1812) & Vujčić-Karlo \& Klipa (1998) & & \\
\hline 6. & Abax parallelepipedus (Piller \& Mitterpacher, 1783) & Vujčić-Karlo \& Klipa (1998) & & \\
\hline 7. & Agonum viduum (Panzer, 1796) & Vujčić-Karlo \& Klipa (1998) & & \\
\hline 8. & Amara sp. & Vujčić-Karlo \& Klipa (1998) & & \\
\hline 9. & Anchomenus dorsalis (Pontoppidan, 1763) & Vujčić-Karlo \& Klipa (1998) & & \\
\hline 10. & Badister dilatatus Chaudoir, 1837 & Vujčić-Karlo \& Klipa (1998) & & \\
\hline 11. & Badister dorsiger (Duftschmid, 1812) & Vujčić-Karlo \& Klipa (1998) & & \\
\hline 12. & Brachinus crepitans (Linne, 1758) & Vujčić-Karlo \& Klipa (1998) & & \\
\hline 13. & Calosoma inquisitor (Linne, 1758) & Vujčić-Karlo \& Klipa (1998) & & \\
\hline 14. & Carabus nemoralis 0.F. Muller, 1764 & Vujčić-Karlo \& Klipa (1998) & 3 & \\
\hline 15. & Carabus granulatus Linne, 1758 & Vujčić-Karlo \& Klipa (1998) & 5,8 & \\
\hline 16. & Carabus ullrichii Germar, 1824 & Vujčić-Karlo \& Klipa (1998) & 4,5 & \\
\hline 17. & Carabus violaceus Linne, 1758 & Vujčić-Karlo \& Klipa (1998) & & \\
\hline 18. & Carabus coriaceus Linne, 1758 & Vujčić-Karlo \& Klipa (1998) & & LC \\
\hline 19. & Carabus cancellatus Illiger, 1798 & Vujčić-Karlo \& Klipa (1998) & 4,5 & LC \\
\hline 20. & Cryptophonus tenebrosus (Dejean, 1829) & Vujčić-Karlo \& Klipa (1998) & & \\
\hline 21. & Diachromus germanus (Linnaeus, 1758) & Vujčić-Karlo \& Klipa (1998) & $2,11,13,14,15$ & \\
\hline 22. & Dyschirius digitatus (Dejean, 1825) & Vujčić-Karlo \& Klipa (1998) & & NT \\
\hline 23. & Elaphrus cupreus Duftschmid, 1812 & Vujčić-Karlo \& Klipa (1998) & & LC \\
\hline 24. & Harpalus distinguendus (Duftschmid, 1812) & Vujčić-Karlo \& Klipa (1998) & & \\
\hline 25. & Harpalus latus (Linne, 1758) & Vujčić-Karlo \& Klipa (1998) & & \\
\hline 26. & Leistus piceus Frölich, 1799 & Vujčić-Karlo \& Klipa (1998) & & \\
\hline 27. & Limodromus assimilis (Paykull, 1790) & Vujčić-Karlo \& Klipa (1998) & & \\
\hline 28. & Limodromus longiventris (Mannerheim, 1825) & Vujčić-Karlo \& Klipa (1998) & & \\
\hline 29. & Loricera pilicornis (Fabricius, 1775) & Vujčić-Karlo \& Klipa (1998) & & LC \\
\hline 30. & Metallina lampros (Herbst, 1784) & Vujčić-Karlo \& Klipa (1998) & & \\
\hline 31. & Metallina properans (Stephens, 1828) & Vujčić-Karlo \& Klipa (1998) & & \\
\hline 32. & Nebria brevicollis (Fabricius, 1792) & Vujčić-Karlo \& Klipa (1998) & & \\
\hline 33. & Panagaeus cruxmajor (Linne, 1758) & & 11 & NT \\
\hline 34. & Pangus scaritides (Sturm, 1818) & Vujčić-Karlo \& Klipa (1998) & & \\
\hline 35. & Patrobus sp. & Vujčić-Karlo \& Klipa (1998) & & \\
\hline 36. & Philochthus biguttatus (Fabricius, 1779) & Vujčić-Karlo \& Klipa (1998) & & \\
\hline 37. & Platynus livens (Gyllenhal, 1810) & Vujčić-Karlo \& Klipa (1998) & & \\
\hline 38. & Poecilus cupreus (Linne, 1758) & Vujčić-Karlo \& Klipa (1998) & & \\
\hline 39. & Pseudoophonus griseus (Panzer, 1796) & & 11 & \\
\hline 40. & Pseudoophonus rufipes (De Geer, 1774) & Vujčić-Karlo \& Klipa (1998) & 11 & \\
\hline 41. & Pterostichus pumilio (Dejean, 1828) & Vujčić-Karlo \& Klipa (1998) & & \\
\hline 42. & Pterostichus ovoideus (Sturm, 1824) & Vujčić-Karlo \& Klipa (1998) & & \\
\hline 43. & Pterostichus strenuus (Panzer, 1796) & Vujčić-Karlo \& Klipa (1998) & & \\
\hline 44. & Pterostichus niger (Schaller, 1783) & Vujčić-Karlo \& Klipa (1998) & & \\
\hline 45. & Pterostichus nigrita (Paykull, 1790) & Vujčić-Karlo \& Klipa (1998) & & \\
\hline 46. & Stomis pumicatus (Panzer, 1796) & Vujčić-Karlo \& Klipa (1998) & & LC \\
\hline
\end{tabular}




\begin{tabular}{|c|c|c|c|c|}
\hline $\begin{array}{l}\text { No. } \\
\text { Br. }\end{array}$ & $\begin{array}{l}\text { Species } \\
\text { Vrsta }\end{array}$ & $\begin{array}{l}\text { Literature } \\
\text { Literatura }\end{array}$ & $\begin{array}{l}\text { This research } \\
\text { Ovo istraživanje }\end{array}$ & IUCN status \\
\hline 47. & Syntomus obscuroguttatus (Duftschmid, 1812) & Vujčić-Karlo \& Klipa (1998) & & \\
\hline 48. & Thalassophilus longicornis (Sturm, 1825) & Vujčić-Karlo \& Klipa (1998) & & \\
\hline 49. & Trechus sp. & Vujčić-Karlo \& Klipa (1998) & & \\
\hline \multicolumn{5}{|c|}{ Cerambycidae } \\
\hline 50. & Aegomorphus clavipes (Schrank, 1781) * & Mikšić (1963) & & \\
\hline 51. & Aegosoma scabricorne (Scopoli, 1763) * & & 11 & LC \\
\hline 52. & Agapanthia cardui (Linnaeus, 1767) * & & 11 & \\
\hline 53. & Agapanthia villosoviridescens (De Geer, 1775) * & & 11 & \\
\hline 54. & Aromia moschata (Linnaeus, 1758) * & & 4,5 & LC \\
\hline 55. & Calamobius filum (Rossi, 1790) * & & 11 & \\
\hline 56. & Cerambyx cerdo Linnaeus, $1758 *$ & Anonymous (2015) & 4 & NT \\
\hline 57. & Cerambyx scopolii Fuessly, $1775^{*}$ & & $6,7,8,13$ & LC \\
\hline 58. & Chlorophorus sartor (Muller, 1766) * & & 13 & LC \\
\hline 59. & Leptura quadrifasciata Linnaeus, 1758 * & & 5 & \\
\hline 60. & Pseudovadonia livida (Fabricius, 1776) * & & 7 & \\
\hline 61. & Rhagium mordax (De Geer 1775) * & & 5 & \\
\hline 62. & Rhagium sycophanta (Schrank 1781) * & & 5 & \\
\hline 63. & Rutpela maculata (Poda, 1761) * & & 7 & \\
\hline 64. & Stenurella nigra (Linnaeus, 1758) * & Mikšić (1963) & & \\
\hline \multicolumn{5}{|c|}{ Chrysomelidae } \\
\hline 65. & Aphthona nonstriata Goeze, 1777 & & 10 & \\
\hline 66. & Cassida murraea Linnaeus, 1767 & & 10,13 & \\
\hline 67. & Chrysochus asclepiadeus (Pallas, 1773) & & 13 & \\
\hline 68. & Chrysolina fastuosa (Scopoli, 1763) & & $1,4,7$ & \\
\hline 69. & Chrysomela populi Linnaeus, 1758 & & 2 & \\
\hline 70. & Crepidodera aurata (Marsham, 1802) & & 8,11 & \\
\hline 71. & Crepidodera pluta (Latreille, 1804) & & 8 & \\
\hline 72. & Cryptocephalus anticus Suffrian, 1848 & & 13 & \\
\hline 73. & Diabrotica virgifera LeConte, 1858 & & 11 & \\
\hline 74. & Donacia bicolora Zschach, 1788 & & 1,8 & \\
\hline 75. & Donacia dentata Hoppe, 1795 & & 10 & \\
\hline 76. & Donacia simplex Fabricius, 1775 & & 1 & \\
\hline 77. & Gastrophysa viridula (De Geer, 1775) & & 8 & \\
\hline 78. & Phaedon cochleariae (Fabricius, 1792) & & 10 & \\
\hline 79. & Smaragdina salicina (Scopoli, 1763) & & 10 & \\
\hline \multicolumn{5}{|c|}{ Coccinellidae } \\
\hline 80. & Calvia decemguttata (Linnaeus, 1758) & & 11 & \\
\hline 81. & Calvia quatuordecimguttata Linnaeus, 1758 & & 8 & \\
\hline 82. & Calvia quindecimguttata (Fabricius, 1777) & & 11 & \\
\hline 83. & Coccinella septempunctata Linnaeus, 1758 & & $8,10,11,14,15$ & \\
\hline 84. & Harmonia axyridis Pallas, 1773 & & $5,8,11,13,15$ & \\
\hline 85. & Hippodamia tredecimpunctata Linnaeus, 1758 & & 15 & \\
\hline 86. & Hippodamia variegata Goeze, 1777 & & 15 & \\
\hline 87. & Propylea quatuordecimpunctata (Linnaeus, 1758) & & 10,13 & \\
\hline 88. & Psyllobora vigintiduopunctata (Linnaeus, 1758) & & 8,11 & \\
\hline 89. & Subcoccinella vigintiquatuorpunctata Linnaeus, 1758 & & 10 & \\
\hline 90. & Vibidia duodecimguttata (Poda, 1761) & & 11 & \\
\hline \multicolumn{5}{|c|}{ Cantharidae } \\
\hline 91. & Rhagonycha fulva (Scopoli, 1763) & & 11 & \\
\hline \multicolumn{5}{|c|}{ Elateridae } \\
\hline 92. & Agriotes sputator (Linnaeus, 1758) * & & 11 & \\
\hline
\end{tabular}




\begin{tabular}{|c|c|c|c|c|}
\hline $\begin{array}{l}\text { No. } \\
\text { Br. }\end{array}$ & $\begin{array}{l}\text { Species } \\
\text { Vrsta }\end{array}$ & $\begin{array}{l}\text { Literature } \\
\text { Literatura }\end{array}$ & $\begin{array}{l}\text { This research } \\
\text { Ovo istraživanje }\end{array}$ & IUCN status \\
\hline 93. & Ampedus glycereus (Herbst, 1784) * & & 9 & NT \\
\hline 94. & Ampedus sanguinolentus (Schrank, 1776) * & & 8,9 & LC \\
\hline 95. & Athous haemorrhoidalis (Fabricius, 1801) * & & $8,9,11$ & \\
\hline 96. & Calambus bipustulatus (Linnaeus, 1767) * & & 5 & LC \\
\hline 97. & Cidnopus pilosus (Leske, 1785) * & & 11,14 & \\
\hline 98. & Elathous impressifrons (Hampe, 1866) * & Schlosser (1878) & & \\
\hline 99. & Melanotus crassicollis (Erichson, 1841) * & & 11 & \\
\hline 100. & Stenagostus rhombeus (Olivier, 1790) * & & 11 & LC \\
\hline 101. & Synaptus filiformis (Fabricius, 1781) * & & 8,11 & \\
\hline \multicolumn{5}{|c|}{ Histeridae } \\
\hline 102. & Hololepta plana (Sulzer, 1776) * & & 8 & \\
\hline \multicolumn{5}{|c|}{ Hydrophilidae } \\
\hline 103. & Hydrophilus piceus (Linnaeus, 1758) & & 11 & \\
\hline \multicolumn{5}{|c|}{ Cetoniidae } \\
\hline 104. & Cetonia aurata (Linnaeus, 1761) * & & $4,5,8,11,13$ & \\
\hline 105. & Gnorimus nobilis (Linnaeus, 1758) * & & 7,8 & LC \\
\hline 106. & Gnorimus variabilis (Linnaeus, 1758) * & & 4 & NT \\
\hline 107. & Oxythyrea funesta (Poda, 1761) * & & 8 & \\
\hline 108. & Protaetia aeruginosa (Linnaeus, 1767) * & & 7 & NT \\
\hline 109. & Protaetia fieberi (Kraatz, 1880) * & & 5 & NT \\
\hline 110. & Tropinota hirta (Poda, 1761) * & & 8 & \\
\hline 111. & Valgus hemipterus (Linnaeus, 1758) * & & 15 & LC \\
\hline \multicolumn{5}{|c|}{ Lucanidae } \\
\hline 112. & Dorcus parallelipipedus (Linnaeus, 1785) * & & 5,7 & LC \\
\hline 113. & Lucanus cervus (Linnaeus, 1758) * & Anonymous (2015) & & NT \\
\hline \multicolumn{5}{|c|}{ Melolonthidae } \\
\hline 114. & Melolontha hippocastani Fabricius, 1801 * & & 5 & \\
\hline 115. & Melolontha melolontha (Linnaeus, 1758) * & & 5 & \\
\hline 116. & Serica brunnea (Linnaeus, 1758) * & & 11 & \\
\hline \multicolumn{5}{|c|}{ Trogidae } \\
\hline 117. & Trox perrisii Fairmaire, 1868 & & 11 & \\
\hline 118. & Trox scaber (Linnaeus, 1767) & & 11 & \\
\hline \multicolumn{5}{|c|}{ Silphidae } \\
\hline 119. & Dendroxena quadrimaculata (Scopoli, 1772) & & 3 & \\
\hline 120. & Necrodes littoralis (Linnaeus, 1758) & & 11 & \\
\hline 121. & Nicrophorus vespillo (Linnaeus, 1758) & & 7,11 & \\
\hline 122. & Oiceoptoma thoracicum (Linnaeus, 1758) & & 7 & \\
\hline 123. & Phosphuga atrata (Linnaeus, 1758) & & $3,4,11$ & \\
\hline 124. & Thanatophilus rugosus (Linnaeus, 1758) & & 7 & \\
\hline \multicolumn{5}{|c|}{ Melandryidae } \\
\hline 125. & Hypulus quercinus (Quensel, 1790) * & Schlosser (1878) & & \\
\hline 126. & Phryganophilus ruficollis (Fabricius, 1798) * & Schlosser (1878) & & NT \\
\hline \multicolumn{5}{|c|}{ Oedemeridae } \\
\hline 127. & Oedemera femorata (Scopoli, 1763) & & 15 & \\
\hline \multicolumn{5}{|c|}{ Pyrochroidae } \\
\hline 128. & Pyrochroa serraticornis (Scopoli, 1763) * & & 5 & \\
\hline 129. & Schizotus pectinicornis (Linnaeus, 1758) * & & 12 & \\
\hline \multicolumn{5}{|c|}{ Tenebrionidae } \\
\hline 130. & Allecula morio (Fabricius, 1787) * & & 11 & \\
\hline 131. & Diaperis boleti (Linnaeus, 1758) * & & 3,5 & \\
\hline 132. & Enoplopus dentipes (Rossi, 1790) * & & 3,5 & \\
\hline \multicolumn{5}{|c|}{ Zopheridae } \\
\hline 133. & Colydium elongatum (Fabricius, 1787) * & & 8 & \\
\hline
\end{tabular}


rective - Cerambyx cerdo Linnaeus, 1758. Twenty-four species have an IUCN Red List status - 15 are Least Concern (LC), while nine are Near Threatened (NT). Of those two categories, ten and seven are saproxylic, respectively, i.e. in some way dependant and/or connected to the decay of wood at least during a part of their life cycle.

\section{DISCUSSION}

\section{RASPRAVA}

With little-to-no data published for other wetlands in Croatia, it is almost impossible to put our results in any meaningful perspective. Tallósi (2008) lists 173 species of Carabidae along the Drava river and in Baranja, including a part of Kopački Rit. Kopački Rit by itself has a total of 275 beetle species, of which 155 are Carabidae (Krčmar, 2014; Kulundžić et al., 2014). Both areas are larger than Turopoljski Lug and contain more habitat types, and were researched more, so their larger number of species is not surprising. Nevertheless, future beetle research in Turopoljski Lug is expected to yield many more additions to the current species list.

Three Natura 2000 species are listed for the site Odransko Polje: Lucanus cervus (Linnaeus, 1758), Graphoderus bilineatus (De Geer, 1774), and C. cerdo, of which we only found the latter. This could be because the forest itself periodically floods, which is not a favourable condition for the larvae of L. cervus. This species probably prefers more elevated and/ or drier locations, possibly outside of the Turopoljski Lug forest. Future research should investigate in more detail its occurrence in and around the forest. The second species, G. bilineatus, is an aquatic beetle living in mostly stagnant permanent waters (Cuppen et al., 2006; Temunović and Turić, 2015). It is fairly rare in Croatia, and the best chance of finding it is by placing funnel traps in suitable aquatic habitats (Temunović and Turić, 2015; Volkova et al., 2013). Since we did not employ this methodology, it is not surprising that we did not find this species. A literature record was found for a fourth Natura 2000 species from Turopoljski Lug - Phryganophilus ruficollis (Fabricius, 1798) (Schlosser, 1878). This species has not been listed on the reference list for Croatia due to a complete lack of recent records since no one looked for it since and there is no monitoring protocol. Therefore, it would be recommendable to invest in targeted research actions to ascertain if $P$. ruficollis is still present in Turopoljski Lug and assess its status if it is.

Although the European Red List of Saproxylic Beetles covers many beetle species at the European level (Nieto and Alexander, 2010), there are still many taxa that are not evaluated at the European level. In Croatia, only the Red List of Carabidae exists, with all other beetle taxa not being evaluated as of yet (Vujčić-Karlo et al., 2007). Due to damaged, sick and rotting trees not being viewed as valuable from the lumber industry's standpoint, they are often removed from forests. However, those trees are of vital importance from a biodiversity standpoint, because one such tree can serve as a home to whole communities of organisms, including saproxylic beetles, for decades. Their removal has been shown to be the gravest threat to both threatened and non-threatened saproxylic beetles in all of Europe (Nieto and Alexander, 2010). Therefore it is certainly recommended to modify current practices and leave old trees, tree stumps and logs in all parts of the forest, as it is already mandated by the Forestry Act (Anonymous, 2005), so some suitable habitat would still remain to ensure the long-term survival of such species (Tvrtković, 1997b). Additionally, Red Listing of other beetle groups should be carried out at the earliest possible convenience, both at the Croatian and European levels, to facilitate better nature conservation practices.

Three of the recorded species can be characterised as rare in Croatia: Trox perrisii Fairmaire, 1868, Gnorimus variabilis (Linnaeus, 1758), and Elathous impressifrons (Hampe, 1866). The first one has only recently been discovered for Croatia, on Ivanščica Mt. and on the Istria peninsula (Koren, 2015; Ziani et al., 2015). This is the third record for this species in Croatia. G. variabilis is rare in Europe and has a fragmented population throughout its range. Declines are reported from a number of states (Mannerkoski et al., 2010). Even though there are several literature records for Croatia (Koča, 1905; Mikšić, 1965; Müller, 1902; Novak, 1952; Schlosser, 1878), there were no recent records till 2015 (Šag, 2015). We found remains of an adult beetle while examining red rotten oak tree trunk in Turopoljski lug in March 2015.

Elater impressifrons is a poorly known beetle. It was described from the vicinity of Zagreb (Hampe, 1866). Schlosser (1878) mentions that the Croatian entomologist Julija Stiegler collected it in Turopoljski Lug forest in wood mould of oak tree hollows. This is so far the only precise known locality for this species. A female specimen of this species from Croatia, without any other collecting details, is deposited in the Coleoptera collection of the Hungarian Natural History Museum (Tamás Németh, personal communication). The species wasn't recorded during this research, suggesting more focused surveys are required in the future.

Two of the recorded species are alien - Harmonia axyridis Pallas, 1773 and Diabrotica virgifera LeConte, 1858. The former, an invasive species that is now widespread in Europe, had first been recorded in Croatia in 2008 (Mičetić Stanković et al., 2010). It is known to have a negative influence on the native coccinellid fauna (Roy and Wajnberg, 2008). Since no previous published records exist for Coccinellidae of Turopoljski Lug, it will be impossible to know the changes in the fauna from before the arrival of H. axyridis. The current situation should be investigated in more 
detail to at least have a baseline to compare future changes, since the 11 coccinellid species recorded for Turopoljski Lug represent only $14 \%$ of the currently known Croatian ladybug fauna (Koren et al., 2012). The second alien species, D. virgifera, is a notable agricultural pest on maize crops. The first records of this species in Croatia were in 1995, near the border with Serbia (Igrc Barčić and Maceljski, 1997). Its expansion westwards was methodically tracked, and it reached the surroundings of Zagreb by 2003 (Igrc Barčić et al., 2003). Since corn is planted on some of the fields around Turopoljski Lug (the authors' personal observation), its occurrence here is not surprising. However, it is unknown to us if it causes extensive damage to crops in the area.

To conserve the remaining wet grasslands within the study area, and all species depending on them, regular mowing and/or grazing should be re-established (Tvrtković, 1997b). This is needed to curb the advance of woody vegetation, especially the invasive Amorpha fruticosa L. However, this should be conducted in a manner that will not be so intense that it proves detrimental to the survival of herbaceous and flowering plants on which many beetle species depend. Additionally, it is possible that the water management measures implemented throughout the years could have, or have already had, a negative impact on aquatic beetles, especially G. bilineatus, due to the disappearance of suitable habitats (see Introduction and Lazowski, 1910). Further research should be conducted in this regard and, if necessary, modify and/or replace existing water management measures with more appropriate ones.

\section{CONCLUSIONS}

\section{ZAKLJUČCI}

With this the Natura 2000 site Odransko Polje, which covers Turopoljski Lug, became one of only several Croatian Natura 2000 sites with a list of known beetle species. Future research, targeting specific Coleoptera groups, should add many more species, especially those that are saproxylic, to the list. A systematic mapping of the Natura 2000 species known from the area would yield much needed conservation data. Current management practices and their effect on the biodiversity of Turopoljski Lug should be evaluated and steps taken to ensure its continued survival and vitality.

\section{ACKNOWLEGMENTS}

\section{ZAHVALE}

We would like to thank the City of Velika Gorica for their support for the implementation of the project "BioOdra 2017", under which this research was carried out. Our thanks also go to Vesna Zadravec, for her photo of the forest. Permits for the work were obtained from the Ministry of the
Environment and Energy (Class: UP/I-612-07/17-48/78, Permit No.: 517-07-1-1-1-17-7). Special thanks go to Tamás Németh from the Hungarian Natural History Museum (NHMUS), for checking our Elateridae identifications.

\section{REFERENCES}

\section{LITERATURA}

- Anonymous, 1979: Council Directive 79/409/EEC of 2 April 1979 on the conservation of wild birds, Official Journal of the European Communities L: 1-18.

- Anonymous, 1992: Council Directive 92/43/EEC of 21 May 1992 on the conservation of natural habitats and of wild fauna and flora, Official Journal of the European Communities L: 7-50.

- Anonymous, 2003: Odluka o proglašenju Turopoljskog luga i vlažnih livada uz rijeku Odru zaštićenim krajolikom, Glasnik Zagrebačke županije 9: 21-21.

- Anonymous, 2005. Zakon o šumama. Narodne novine 2005.

- Anonymous, 2008: Strategic Framework and guidelines for the future development of the List of Wetlands of Intaernational Importance of the Convention on Wetlands (Ramsar, Iran, 1971), Third edition, as adopted by Resolution VII.11 (COP7, 1999) and amended by Resolutions VII.13 (1999), VIII.11 and VIII.33 (COP8, 2002), IX.1 Annexes A and B (COP9, 2005), and X.20 (COP10, 2008).

- Anonymous, 2015. Natura 2000 Standard Data Form. HR2000415 Odransko polje.

- Ballerio, A., Rey, A., Uliana, M., Rastelli, M., Rastelli, S., Romano, M., Colacurcio, L., 2010. Coleotteri Scarabeoidei d'Italia. CDROM.

- Bense, U., 1995. Bockkäfer : illustrierter Schlüssel zu den Cerambyciden und Vesperiden Europas = Longhorn beetles. Margraf Verlag, Weikersheim.

- Biszak, E., Kulovits, H., Biszak, S., Timár, G., Molnár, G., Székely, B., Jankó, A., Kenyeres, I., 2014. Cartographic heritage of the Habsburg Empire on the web: the MAPIRE initiative. Presented at the 9th International Workshop on Digital Approaches to Cartographic Heritage, ICA Commission on Digital Technologies in Cartographic Heritage, Eötvös Loránd University, Budapest, p. 6.

- Bordy, B., Doguet, S., Debreuil, M., 2012. Les Donaciinae de France (Coleoptera, Chrysomelidae). Rutilans \& Magellanes, Villelongue-dels-Monts.

- Cálix, M., Alexander, K.N.A., Nieto, A., Dodelin, B., Soldati, F., Telnov, D., Vazquez-Albalate, X., Aleksandrowicz, O., Audisio, P., Istrate, P., Jansson, N., Legakis, A., Liberto, A., Makris, C., Merkl, O., Mugerwa Pettersson, R., Schlaghamersky, J., Bologna, M.A., Brustel, H., Buse, J., Novák, V., Purchart, L., 2018. European Red List of Saproxylic Beetles. IUCN, Brussels.

- Cuppen, J., Koese, B., Sierdsema, H., 2006. Distribution and habitat of Graphoderus bilineatus in the Netherlands (Coleoptera: Dytiscidae). Nederlandse Faunistische Mededelingen 24, 29-40.

- Curletti, G., Rastelli, M., Rastelli, S., Tassi, F., 2003. Coleotteri Buprestidi d'Italia. CD-ROM.

- de Jong, Y., Verbeek, M., Michelsen, V., Bjørn, P. de P., Los, W., Steeman, F., Bailly, N., Basire, C., Chylarecki, P., Stloukal, E., Hagedorn, G., Wetzel, F., Glöckler, F., Kroupa, A., Korb, G., Hoffmann, A., Häuser, C., Kohlbecker, A., Müller, A., Güntsch, A., Stoev, P., Penev, L., 2014. Fauna Europaea - all European animal 
species on the web. Biodiversity Data Journal 2, 1-35. https://doi. org/10.3897/BDJ.2.e4034

- Freude, H., 1971. 12. Familie: Silphidae (Aaskäfer), in: Freude, H., Harde, K.W., Lohse, G.A. (Eds.), Die Käfer Mitteleuropas. Goecke \& Evers Verlag, Krefeld, pp. 190-201.

- Hampe, C., 1866. Beschreibung einiger neuen Käfer. Berliner entomologische Zeitschrift 10, 371-375. https://doi.org/10.1002/ mmnd.18660100407

- Igrc Barčić, J., Maceljski, M., 1997. Kukuruzna zlatica (Diabrotica virgifera virgifera LeConte - Col.:Chrysomelidae) - novi štetnik u Hrvatskom podunavlju. Agronomski glasnik 59, 429-443.

- Igrc Barčić, J., Bažok, R., Maceljski, M., 2003. Research on the western corn rootworm (Diabrotica virgifera virgifera LeConte, Coleoptera: Chrysomelidae) in Croatia (1994-2003). Entomologia Croatica 7, 63-83.

- Junk, W.J., An, S., Finlayson, C.M., Gopal, B., Květ, J., Mitchell, S.A., Mitsch, W.J., Robarts, R.D., 2013. Current state of knowledge regarding the world's wetlands and their future under global climate change: a synthesis. Aquatic Sciences 75, 151-167. https://doi.org/10.1007/s00027-012-0278-z

- Koča, G., 1905. Popis tvrdokrilaca (kornjaša) vinkovačke okolice. Glasnik Hrvatskoga Naravoslovnoga Društva 17, 119-212.

- Koren, T., Hlavati, D., Rojko, I., Zadravec, M., 2012. First checklist of ladybirds (Coleoptera: Coccinellidae) of Croatia along with new faunistical records. Acta entomologica serbica 17, 107-122.

- Koren, T., 2015. The first record of Trox perrisii Fairmaire, 1868 in Croatia. Entomologia Croatica 19, 31-35.

- Krčmar, S., 2014. List of insect fauna (Insecta) of Kopački Rit Nature Park (NE Croatia). Türk. entomol. bült. 4, 15-39.

- Kulundžić, K., Turić, N., Vignjević, G., Merdić, E., 2014. Research into scarab beetles (Scarabaeoidea) in Kopački Rit Nature Park. Entomologia Croatica 18, 37-47.

- Laibner, S., 2000. Elateridae of the Czech and Slovak Republics. Kabourek, Zlin.

- Lazowski, E., 1910. Povijest plemenite općine Turopolja nekoć zvane Zagrebačko polje. Antun Scholz, Zagreb.

- Lompe, A., 2009. Hololepta [WWW Document]. Käfer Europas. URL http://www.coleo-net.de/coleo/texte/hololepta.htm (accessed 11.29.17).

- Mannerkoski, I., Hyvärrinen, E., Campanaro, A., Alexander, K., Büche, B., Dodelin, B., Mason, F., Pettersson, R., Mico, E., Méndez, M., 2010. Gnorimus variabilis. The IUCN Red List of Threatened Species 2010: e.T157887A5166091. International Union for Conservation of Nature.

- Mičetić Stanković, V., Koren, T., Stanković, I., 2010. The Harlequin ladybird continues to invade southeastern Europe. Biological Invasions 13, 1711-1716.

- Mikšić, R., 1958. Scarabaeidae Jugoslavije I. dio. Naučno društvo NR Bosne i Hercegovine, Knjiga VI, Sarajevo.

- Mikšić, R., 1963. Prilog poznavanju faune strizibuba (Cerambycidae) Jugoslavije. Acta biologica 3, 55-188.

- Mikšić, R., 1965. Scarabaeidae Jugoslavije III. dio. Naučno društvo Bosne i Hercegovine, Knjiga XXV, Sarajevo.

- Müller, J., 1902. Lucanidae et Scarabaeidae Dalmatiae. Verhandlungen des zoologisch-botanischen Vereins in Wien 52, 438466.
- Nedvěd, O., 2015. Brouci čeledi slunéčkovití (Coccinellidae) střední Evropy = Ladybird beetles (Coccinellidae) of Central Europe. Academic Press, Prague.

- Nieto, A., Alexander, K.N.A., 2010. European Red List of Saproxylic Beetles. IUCN ; Publications Office of the European Union, [Gland] : Luxembourg.

- Novak, P., 1952. Kornjaši jadranskog primorja. Jugoslavenska akademija znanosti i umjetnosti, Zagreb.

- Novák, V., 2014. Brouci čeledi potemníkovití (Tenebrionidae) střední Evropy =: Beetles of the family Tenebrionidae of Central Europe, Vydání první. ed, Zoologické klíče = Zoological keys. Academia, Praha.

- Petersen, H., Luxton, M., 1982. A comparative analysis of soil fauna populations and their role in decomposition. Oikos 39, 288-388.

- Roy, H., Wajnberg, E., 2008. From biological control to invasion: the ladybird Harmonia axyridis as a model species. BioControl 53, 1-4. https://doi.org/10.1007/s10526-007-9127-8

- Šag, M., 2015. Saproksilni kornjaši kao indikatori očuvanosti šumskih ekosustava (master thesis). Sveučilište Josipa Jurja Strossmayera, Odjel za biologiju, Osijek.

- Sama, G., 2002. Northern, Western, Central and Eastern Europe, British Isles and continental Europe from France (excl. Corsica) to Scandinavia and Urals, Atlas of the Cerambycidae of Europe and the Mediterranean area. Kabourek, Zlín.

- Schlosser, J.K., 1878. Fauna kornjašah Trojedne kraljevine. Svezak drugi. Jugoslavenska akademija znanosti i umjetnosti, Zagreb.

- Šustek, Z., 1981. Mrchožroutovití Československa (Coleoptera, Silphidae) $=$ Key to identification of insects: Carrion beetles of Czechoslovakia (Coleoptera, Silphidae), Moravské tiskařské závody, n.p. Olomouc, závod 19. ed. Zprávy Československé Společnosti Entomologické při ČSAV, Klíče k určování hmyzu, Opava.

- Sutherland, W.J., Pullin, A.S., Dolman, P.M., Knight, T.M., 2004. The need for evidence-based conservation. Trends in Ecology \& Evolution 19, 305-308. https://doi.org/10.1016/j.tree.2004.03.018

- Tallósi, B., 2008. Population-level baseline surveying and preparative investigations for the monitoring of carabid beetles (Coleoptera, Carabidae) in areas along the Drava river and in Baranja (Croatia), in: Purger, J.J. (Ed.), Biodiversity Studies along the Dravaa River. University of Pécs, pp. 165-220.

- Temunović, M., Turić, N., 2015. Nacionalni programi za praćenje stanja očuvanosti vrsta u Hrvatskoj. Dvoprugasti kozak Graphoderus bilineatus.

- Trautner, J., Geigenmüller, K., 1987. Tiger Beetles, Ground Beetles: Illustrated key to the Cicindelidae and Carabidae of Europe. Druckerei Fritz Steinmeier, Nördlingen.

- Turin, H., Penev, L., Casale, A. (Eds.), 2003. The Genus Carabus in Europe: a synthesis, Fauna Europaea evertebrata. Pensoft Publishers ; European Invertebrate Survey, Sofia ; Moscow : Leiden.

- Tvrtković, N., 1997a. Karakteristike istraživanog područja, in: Zaštita staništa i biološke raznolikosti na području Turopolja (Rezultati prve godine istraživanja, ožujak - studeni 1997.). Hrvatski prirodoslovni muzej, Zagreb, p. 88.

- Tvrtković, N., 1997b. Zaštita staništa i biološke raznolikosti na području Turopolja (Rezultati prve godine istraživanja, ožujak - studeni 1997.) (Elaborat). Hrvatski prirodoslovni muzej, Zagreb. 
- Volkova, P., Dzhafarova, A., Fedorova, D., Gladchenko, M., Karnayeva, A., Pozdnyakov, O., Slobodkina, Y., Tilipman, D., Petrov, P., 2013. Effect of two types and different quantities of bait on the efficiency of funnel traps for diving beetles (Coleoptera: Dytiscidae), with special emphasis on Graphoderus bilineatus DeGeer, 1774. Latvijas Entomologs 52, 119-129.

- Vujčić-Karlo, S., Brigić, A., Šerić Jelaska, L., Kokan, B., Hrašovec, B., 2007. Crveni popis ugroženih vrsta trčaka (Coleoptera, Carabidae) u Hrvatskoj.

- Vujčić-Karlo, S., Klipa, M., 1998. 2.2. Fauna trčaka Turopoljskog luga, in: Tvrtković, N. (Ed.), Rezultati druge godine bioloških is- traživanja (1998) uz preporuku za zaštitu i korištenje u poučne i turističke svrhe. Hrvatski prirodoslovni muzej, Zagreb, pp. 83-99.

- Warchałowski, A., 2003. Chrysomelidae: the leaf-beetles of Europe and the Mediterranean area. Natura Optima dux Foundation, Warszawa.

- Warchałowski, A., 2010. The Palearctic Chrysomelidae. Identification keys. Natura Optima Dux Foundation, Warszawa.

- Ziani, S., Bezděk, A., Branco, T., Hillert, O., Jákl, S., Král, D., Mantič, M., Rößner, E., Sehnal, R., 2015. New country records of Scarabaeoidea (Coleoptera) from the Palearctic Region. Insecta Mundi 0409, 1-36.

\section{SAŽETAK}

Vlažna staništa pružaju mnoge usluge ekosustava, npr. služe kao prirodne retencije poplavnih voda, a mogu biti i područja za rekreaciju šire javnosti. Predstavljaju i životno važna staništa za brojne životinjske vrste, stoga su mnoga vlažna staništa pod nekim stupnjem zaštite. Unatoč tomu, fauna mnogih vlažnih staništa i dalje je većinom nepoznata, posebice po pitanju kornjaša. Nepoznavanje faune određenog područja otežava upravljanje istim. Jedna takva lokacija je šuma Turopoljski lug, smještena jugoistočno od glavnog grada Zagreba. Terensko istraživanje provedeno je od ožujka do rujna 2017. Koristile su se četiri metode: kečiranje, zamke s mamcima na stablima, svjetlosne zamke s UV žaruljama po noći i sakupljanje rukom. Rezultatima je pridodano i nekoliko nalaza od ranije. Ukupan broj poznatih vrsta kornjaša za Turopoljski lug podignut je s 51 na 133. Devet vrsta imaju gotovo ugrožen IUCN status ugroženosti, od kojih je sedam saproksilnog načina života. Iz područja su poznate tri vrste navedene u Dodacima II i IV Direktive o staništima, od kojih smo zabilježili samo Cerambyx cerdo. Također, pronađen je zanemaren nalaz iz literature za četvrtu - Phryganophilus ruficollis. Potrebno je preispitati i, po potrebi, izmijeniti dosadašnji način upravljanja šumom. Buduća usmjerena istraživanja određenih skupina kornjaša trebala bi uroditi dodatnim povećanjem broja vrsta poznatih za lug, dok bi ciljano kartiranje prisutnosti vrsta s Dodataka iznjedrilo prijeko potrebne podatke za zaštitu prirode.

KLJUČNE RIJEČI: poplavna šuma, Ekološka mreža Natura 2000, Cerambyx cerdo, Phryganophilus ruficollis, Trox perrisii, zaštićena područja 